\title{
Two new Oedothorax Bertkau, 1883 from eastern India (Aranei: Linyphiidae)
}

\author{
Ава новых вида Oedothorax Bertkau, 1883 из восточной Индии \\ (Aranei: Linyphiidae)
}

\section{Andrei V. Tanasevitch \\ A.В. Танасевич}

\begin{abstract}
A.N. Severtsov Institute of Ecology and Evolution, Russian Academy of Sciences, Leninsky prospekt 33, Moscow 119071, Russia. E-mail: tanasevitch@gmail.com

Институт проблем экологии и эволюции им. А.Н. Северцова РАН, Ленинский проспект 33, Москва 119071, Россия.
\end{abstract}

KEY WORDS: taxonomy, spiders, Erigoninae, Oriental Region, Meghalaya.

КЛЮЧЕВЫЕ СЛОВА: таксономия, пауки, Erigoninae, Ориентальное царство, Meghalaya.

ABSTRACT. Two new species, Oedothorax unciger sp.n. and $O$. sohra sp.n., are described from the state of Meghalaya, eastern India. O. unciger sp.n. differs well from other congeners by the presence of characteristic, hook-shaped outgrowth on the convector. $O$. sohra sp.n. seems to be especially similar to $O$. myanmar Tanasevitch, 2017, but is distinguished by a thinner dorsal tibial process of the palp, as well as by both the distal suprategular apophysis and the distal apophysis of the convector being longer.

How to cite this article: Tanasevitch A.V. 2020. Two new Oedothorax Bertkau, 1883 from eastern India (Aranei: Linyphiidae) // Arthropoda Selecta. Vol.29. No.1. P.127-131. doi: 10.15298/arthsel. 29.1.11

РЕЗЮМЕ. Два новых вида, Oedothorax unciger sp.n. и O. sohra sp.n., описаны из штата Мегхалая (восточная Индия). O. unciger sp.n. хорошо отличается от других представителей рода наличием специфического крючковидного отростка на конвекторе. O. sohra sp.n. близок к O. myanmar Tanasevitch, 2017, но отличается более тонким дорсальным выростом голени пальпы и более длинными дистальным супратегулярным отростком и дистальным отростком конвектора.

\section{Introduction}

At present, the spider fauna of India is known to contain 14 species of Oedothorax Bertkau, in Förster et Bertkau, 1883. Six of them are from the Himalaya, likely Palaearctic, encountered at 1200-2600 m a.s.1. The remaining eight Oedothorax have been described from uplands within the Oriental part of the country, at 900-2150 m a.s.1. [Thaler, 1987; Tanasevitch 2015, 2016, 2017]. Another two new species of Oedothorax, taken by Konstantin Tomkovich (Moscow) from the highlands of Meghalaya, within the Oriental part of
India, have been located in the collection of the Zoological Museum of the Moscow State University, Moscow, Russia (ZMMU). Their descriptions are the subject of the present paper.

\section{Material and methods}

This paper is based on the spider material kept in the ZMMU. All specimens are preserved in $70 \%$ ethanol and have been studied using a MBS-9 stereo microscope. A Levenhuk C-800 digital camera was applied for taking some pictures. The sequence of leg segment measurements is as follows: femur + patella + tibia + metatarsus + tarsus. All measurements are given in millimeters. The chaetotaxy is given in a formula, e.g., 2.2.1.1, which refers to the number of dorsal spines on tibiae I-IV. Scale bars in the figures correspond to $0.1 \mathrm{~mm}$ unless indicated otherwise. Figure numbers are given above the scale lines, the alternative distance below. The terminology of copulatory organs mainly follows that of Merrett [1963], Hormiga [2000] and Tanasevitch [1998, 2015].

The following abbreviations are used in the text and figures: a.s.1. - above sea level, D — duct, DAC — distal apophysis of convector, DSA - distal suprategular apophysis, E - embolus, H - hook, LEC - lateral extension of convector, LT - lateral tooth of DSA, MBC - main body of convector, $\mathrm{Mt}$ - metatarsus, $\mathrm{P}$ - paracymbium, $\mathrm{Pr}-$ protegulum, Ti - tibia, TmI - position of trichobothrium on metatarsus I.

\section{Descriptions}

Oedothorax unciger sp.n. Figs $1-3,7-12$.

HOLOTYPE $\sigma^{\top}$ (ZMMU), INDIA, Meghalaya, Sohra, plateau, 1320 m a.s.1., 14-26.XII.2013, leg. K.P. Tomkovich.

PARATYPE. $1 \sigma^{7}$ (ZMMU), together with holotype.

NAME. The specific epithet is a noun in apposition, meaning "bearing a hook", referring to the presence of a characteristic hook on the convector of the male palp. 

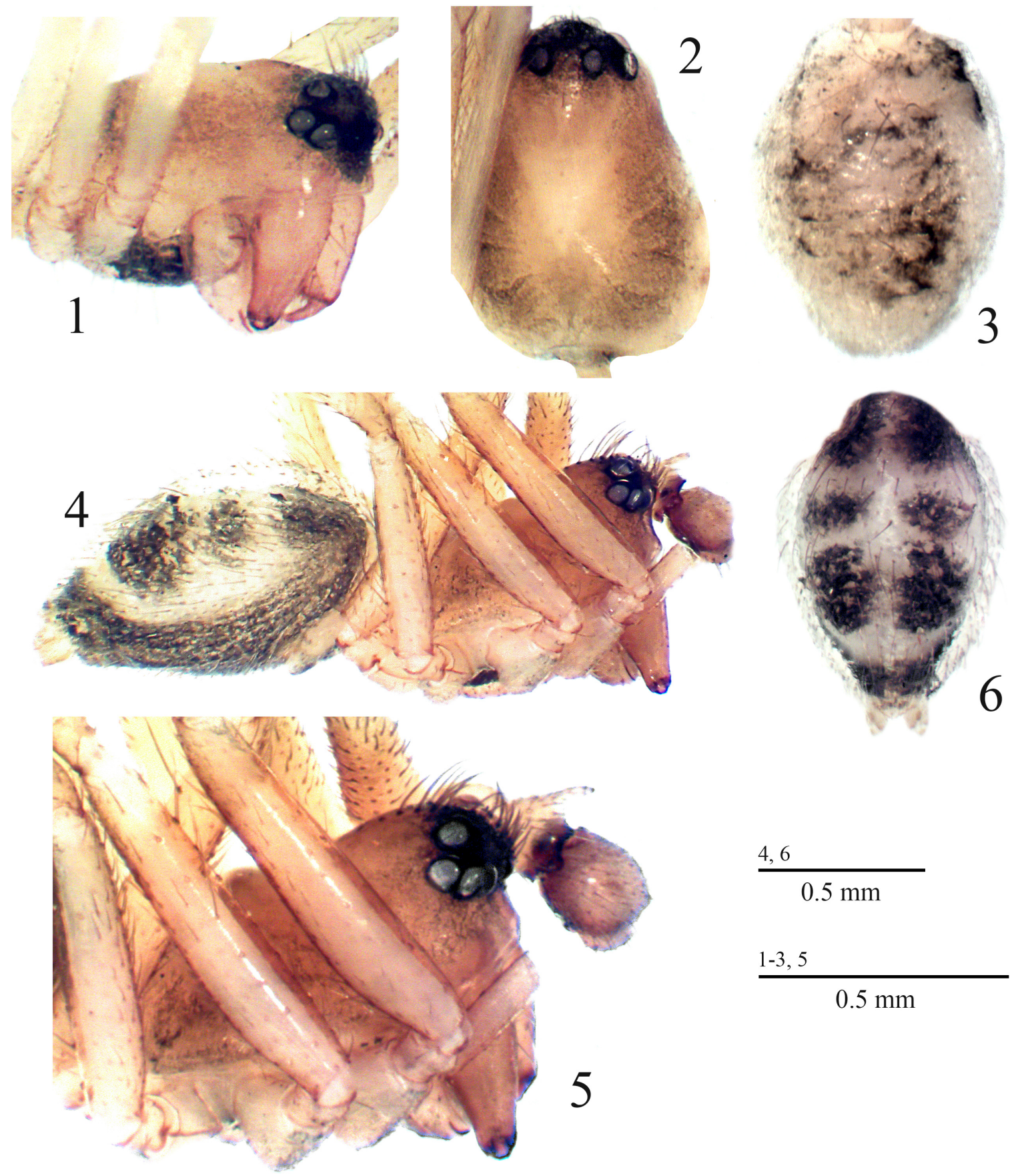

\section{$1-3,5$}

$0.5 \mathrm{~mm}$

Figs 1-6. Pictures of Oedothorax unciger sp.n. (1-3), $\sigma^{7}$ holotype, and $O$. sohra sp.n. (4-6), $\sigma^{7}$ holotype. 1 - prosoma, anterolateral view; 2, 5 - prosoma, dorsal and lateral views, respectively; 3, 6 - abdomen, dorsal view; 4 - habitus, lateral view.

Рис. 1-6. Фотографии Oedothorax unciger sp.n. (1-3), голотип О7 и O. sohra sp.n. (4-6), голотип О7. 1 - головогрудь, вид спереди и сбоку; 2,5 - головогрудь, вид сверху и сбоку, соответственно; 3,6 - брюшко, вид сверху; 4 - внешний вид сбоку.

DESCRIPTION. Male (holotype). Total length 1.70 . Carapace unmodified, 0.75 long, 0.65 wide, pale brown to yellow, with a wide, grey margin. Head part of carapace not elevated, ocular area with numerous, short, slightly curved spines, as shown in Figs 1-2. Chelicerae 0.28 long, unmodified, a mastidion absent. Legs yellow. Leg I, 3.48 long $(1.00+0.20+0.85+0.85+0.58)$, IV, 3.19 long $(0.90+$ $0.18+0.80+0.83+0.48)$. Chaetotaxy: 2.2 .1 .1 , spines $2-3 \mathrm{x}$ as long as diameter of corresponding leg segment. Each metatarsus with a trichobothrium. TmI 0.78. Palp (Figs 712): Length of patella subequal to tibia. Tibia slightly elongated dorsally, faintly bifid apically. Distal part of paracymbium bearing numerous, somewhat curved spines. Protegulum well-developed. Distal suprategular apophysis short, spoon-shaped. Embolus very small, bent near middle. Convector large, its distal apophysis relatively short, pointed. 


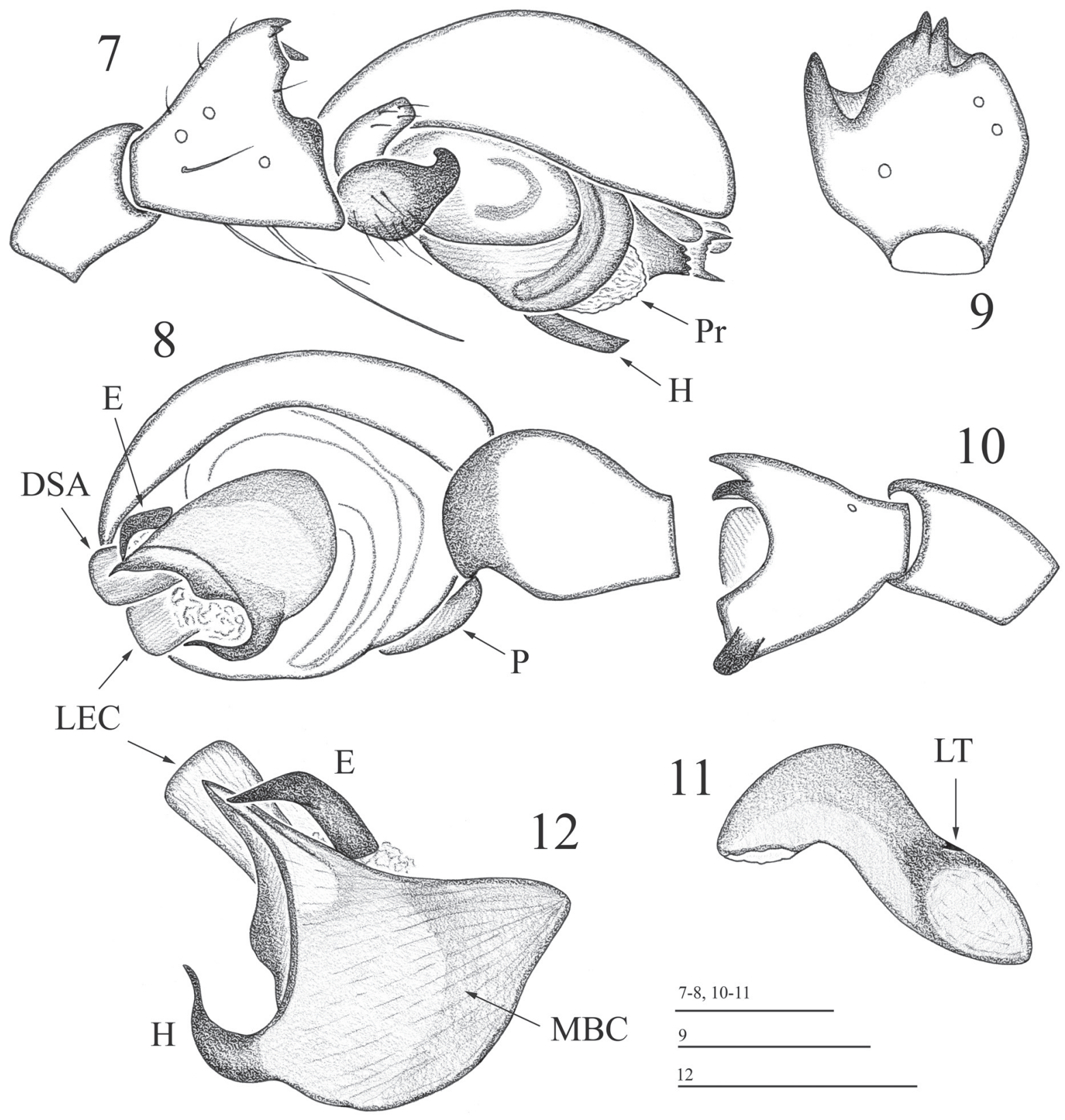

Figs 7-12. Details of male palpal structure of Oedothorax unciger sp.n., paratype. 7-8 - right palp, retro- and ventro-prolateral views, respectively; 9 - palpal tibia, dorsal view; 10 - palpal tibia and patella retrolateral view; 11 - distal suprategular apophysis; $12-$ embolic division.

Рис. 7-12. Детали строения пальпы самца Oedothorax unciger sp.n., paratype. 7-8 - правая пальпа, ретро- и вентропролатерально, соответственно; 9 - голень пальпы, вид сверху; 10 — голень пальпы и колено, пролатерально; 11 - дистальный супратегулярный отросток; 12 - эмболюсный отдел.

Lateral extention of convector large, a flat and wide apophysis. Abdomen in poor condition, 0.80 long, 0.60 wide, dorsal pattern partly obliterated, as shown in Fig. 3. Paratype completely devoid of an abdomen.

Female unknown.

TAXONOMIC REMARKS. The new species differs distinctly from other congeners by the presence of a characteristic hook-shaped outgrowth in the lower part of the convector.
DISTRIBUTION. Only known from the type locality.

\section{Oedothorax sohra sp.n.}

Figs 4-6, 13-18.

HOLOTYPE O' (ZMMU), INDIA, Meghalaya, Sohra, plateau, 1320 m a.s.1., 14-26.XII.2013, leg. K.P. Tomkovich.

NAME. The specific name is a noun in apposition taken from the name of the type locality. 

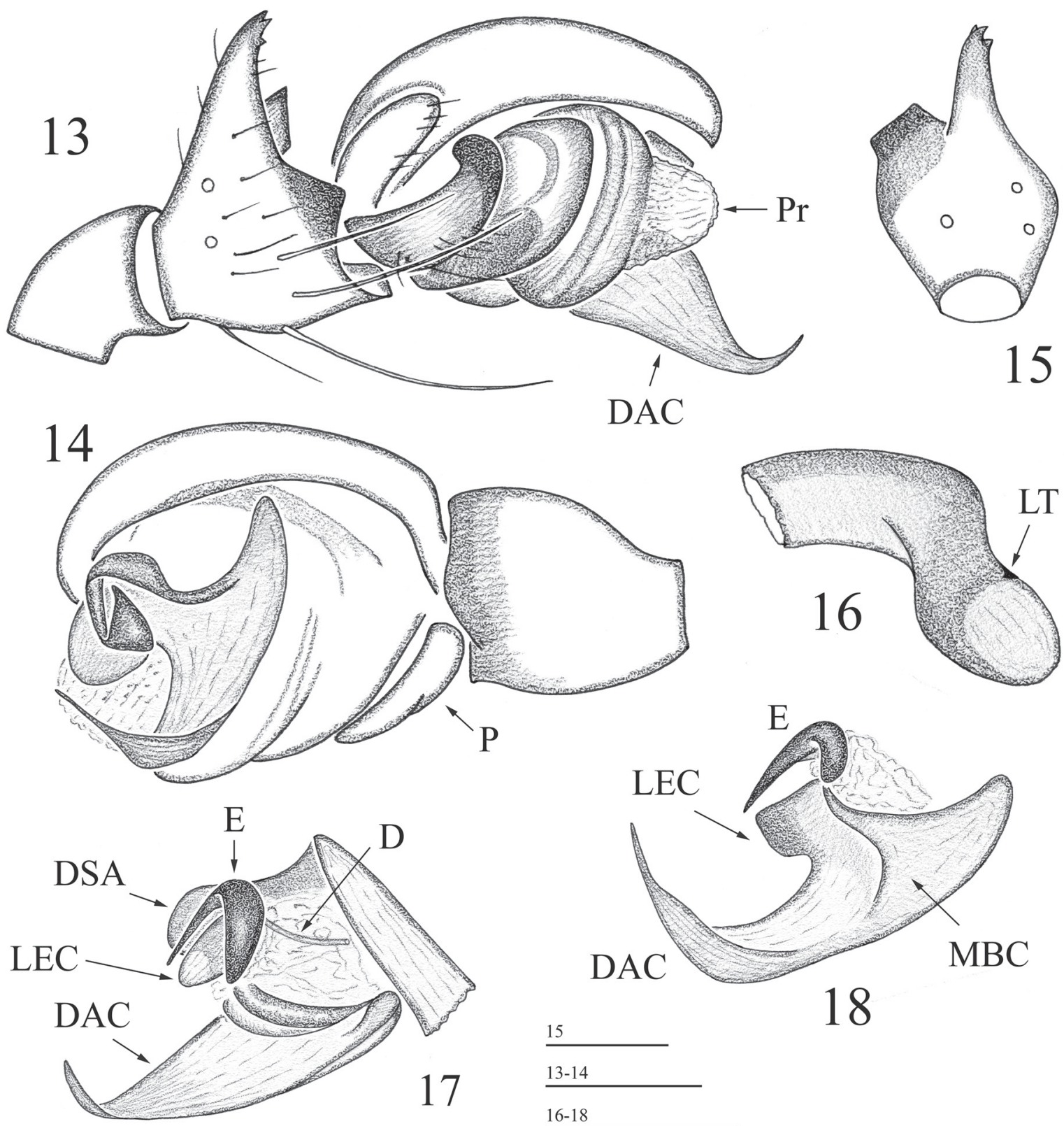

DAC

Figs 13-18. Details of male palpal structure of Oedothorax sohra sp.n., ơ holotype. 13-14 - right palp, retro- and ventro-prolateral views, respectively; 15 - palpal tibia, dorsal view; 16 - distal suprategular apophysis; 17-18 - embolic division, different aspects.

Рис. 13-18. Детали строения пальпы самца Oedothorax sohra sp.n., голотип О7. 13-14 - правая пальпа, ретро- и вентропролатерально, соответственно; 15 - голень пальпы, вид сверху; 16 - дистальный супратегулярный отросток; 17-18 эмболюсный отдел, различные аспекты.

DESCRIPTION. Male (holotype). Total length 1.98 . Carapace unmodified, 0.98 long, 0.75 wide, pale brown. Head part of carapace slightly protruded forward, bearing numerous, short, slightly curved spines, as shown in Figs 4 5. Chelicerae 0.38 long, unmodified, a mastidion absent. Legs pale brown to yellow. Leg I, 3.28 long $(0.90+0.25+$ $0.85+0.78+0.50), \mathrm{IV}, 3.37$ long $(0.93+0.25+0.88+0.83$ $+0.48)$. Chaetotaxy: 2.2 .1 .1 , spines $2-2.5 \mathrm{x}$ as long as diameter of corresponding leg segment. Each metatarsus with a trichobothrium. TmI 0.61. Palp (Figs 13-18): Patella shorter than tibia. Tibia dorsally with a long and slender process terminating in 2-3 denticles. Prolateral tibial outgrowth keelshaped. Paracymbium relatively large, its distal part bearing strong, somewhat curved spines. Protegulum well-developed. Distal suprategular apophysis short, spoon-shaped. Embolus very small, bent near middle. Convector large, complex, its distal apophysis very long, gradually tapering and curved distad. Lateral extention of convector short and wide. Abdomen 1.10 long, 0.70 wide, dorsal pattern as in Fig. 6. 
Female unknown

TAXONOMIC REMARKS. Oedothorax sohra sp.n. seems to be especially similar to $O$. myanmar Tanasevitch, 2017, the latter species described from Myanmar [Tanasevitch, 2017]. The new species is distinguished by the thinner dorsal tibial process, as well as by both the distal suprategular apophysis and the distal apophysis of the convector being longer. The shape of the distal suprategular apophysis resembles that of $O$. uncus Tanasevitch, 2015; the structure of the embolic division is similar to that of $O$. cunur Tanasevitch, 2015. From these two latter species, $O$. sohra sp.n. differs clearly by small, but distinct structural details of the palp.

DISTRIBUTION. Only known from the type locality.

Acknowledgements. I am most grateful to Kirill Mikhailov (ZMMU) for the access to the arachnological collections under his care. I also thank Sergei Golovatch (Moscow) for editing an advanced draft of the manuscript. This study was supported by the Presidium of the Russian Academy of Sciences, Program No. 41 "Biodiversity of natural systems and biological resources of Russia".

\section{References}

Hormiga G. 2000. Higher level phylogenetics of erigonine spiders (Araneae, Linyphiidae, Erigoninae) // Smithsonian Contributions to Zoology. No.609. P.1-160.

Merrett P. 1963. The palpus of male spiders of the family Linyphiidae // Proceedings of the Zoological Society of London. Vol.140. P.347-467.

Tanasevitch A.V. 1998. New Oedothorax Bertkau, 1883 from Nepal (Arachnida, Araneae, Linyphiidae) // Bonner Zoologische Beiträge. Bd.47. Nr.3-4. P.429-441.

Tanasevitch A.V. 2015. Notes on the spider genus Oedothorax Bertkau, 1883 with description of eleven new species from India (Linyphiidae: Erigoninae) // Revue suisse de Zoologie. T.122. Fasc.2. P.381-398.

Tanasevitch A.V. 2016. A case of disjunct montane linyphiid species (Araneae) in the Palaeotropics, with notes on synonymy and the description of a new species // Revue suisse de Zoologie. T.123. Fasc.2. P.235-240.

Tanasevitch A.V. 2017. New species and new records of linyphiid spiders from the Indo-Malayan Region (Araneae: Linyphiidae) // Zootaxa. Vol.4227. No.3. P.325-346.

Thaler K. 1987. Über einige Linyphiidae aus Kashmir (Arachnida: Araneae) // Courier Forschungsinstitut Senckenberg. Bd.93. S.33-42.

Responsible editor K.G. Mikhailov 